\title{
WALKA O PRZYWRÓCENIE POLSKIEJ PAMIĘCI ZBIOROWEJ DZIEJÓW IV ZARZĄDU GŁÓWNEGO WIN PO 1950 ROKU
}

\begin{abstract}
Streszczenie. W artykule przedstawione zostały zmagania środowiska patriotycznego z władzą komunistyczną, która najpierw chciała zniszczyć dobre imię IV Zarządu Głównego WiN oraz wszystkich działaczy niepodległościowych, a następnie zetrzeć wszelki ślad po ich istnieniu. Po okrutnym śledztwie członkowie IV Zarządu zostali osądzeni w pokazowym procesie, którego przebieg był relacjonowany przez radio. Nie pozostało to bez odpowiedzi. Wśród głosu oburzenia znajdował się list robotników wrocławskich, przechowywany przez Urząd Bezpieczeństwa. W walkę o godną pamięć włączył się również Kościół, a w późniejszym okresie Solidarność. Wszystkie działania podejmowane, aby przechować pamięć o IV Zarządzie Głównym WiN spotykały się ze piętnowaniem przez ówczesną władzę komunistyczną. Mimo to prowadzone były dalsze działania. Powstały symboliczne mogiły, gdyż miejsce spoczynku ich ciał do dziś nie jest znane. Ważnym i niezwykle bogatym źródłem są grypsy z celi śmierci pisane przez prezesa IV Zarządu - Łukasza Cieplińskiego. Do przygotowania artykułu wykorzystano źródła archiwalne, wspomnienia, materiały prasowe oraz opracowania.
\end{abstract}

Słowa kluczowe: Łukasz Ciepliński, Zrzeszenie Wolność i Niezawisłość, IV Zarząd Główny WiN, WiN, pamięć.

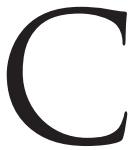

złonkowie IV Zarządu Głównego Zrzeszenia „Wolność i Niezawisłość" swoją działalność niepodległościową rozpoczęli w czasie II wojny światowej na okupowanej Rzeszowszczyźnie. Stojący na ich czele, Łukasz Ciepliński jako jedyny pochodził z Wielkopolski, ale również działał konspiracyjnie na wspomnianym terenie. Swoją walkę z niemieckim 
agresorem rozpoczął już od wybuchu wojny. Jako zawodowy żołnierz walczył na froncie zachodnim, a następnie brał udział w obronie Warszawy w 1939 r. Po przejściu na Węgrzech przeszkolenia konspiracyjnego objął dowództwo jako komendant Obwodu, później inspektor Inspektoratu ZWZ-AK Rzeszów. Wśród jego współpracowników znaleźli się również: Adam Lazarowicz, Józef Batory, Józef Rzepka, Karol Chmiel, Mieczysław Kawalec, Franciszek Błażej i Ludwik Kubik, którzy zostali później zaangażowani przez Łukasza Cieplińskiego do działalności w Zrzeszeniu WiN, a następnie tworzenia IV Zarządu Głównego.

Po aresztowaniu 5 stycznia 1947 r. Wincentego Kwiecińskiego, prezesa III Zarządu Głównego WiN, Łukasz Ciepliński objął prezesurę w najcięższym czasie dla Zrzeszenia. Odbyło się już sfałszowane referendum, będące nie tylko ważnym testem przez wyborami parlamentarnymi, ale również pokazem siły nowej władzy. Wybory z 19 stycznia 1947 r. również zostały sfałszowane. Przeprowadzona zimą tegoż roku II amnestia przyniosła dekonspiracje i liczne aresztowania byłych członków Armii Krajowej. Trafnie ocenił to Janusz Kurtyka pisząc:

Prezesura Cieplińskiego była najbardziej heroicznym okresem w historii WiN, przypadała bowiem na czas załamania się ducha społeczeństwa po sfałszowanych przez komunistów wyborach, rozległych represji wobec legalnego opozycyjnego PSL i zapoczątkowania likwidacji PPS ${ }^{1}$.

Sfałszowanie wyborów parlamentarnych było największym ciosem dla działaczy WiN. Głównym celem organizacji było doprowadzenie do zwycięstwa demokratycznych sił politycznych w wolnych wyborach, których gwarantem miały być państwa Zachodu. Narzucenie Polsce władzy komunistycznej i w konsekwencji sowietyzacja kraju była ostateczną klęską, której WiN nie mógł zapobiec.

Działając w tak trudnym okresie ostatni prezes musiał odznaczać się niezwykłymi zdolnościami organizacyjnymi, ale również ogromną wolą wytrwania przy ideałach, którym się poświęcił. Stanisław Kluz, związany bezpośrednio z Zrzeszeniem WiN, tak w swojej publikacji charakteryzował ostatni zarząd i jego prezesa:

Ciepliński wprowadza WIN na najwyższy szczebel w historii jego istnienia, tak pod względem organizacyjnym, jak i ideowym. Zdolny organizator, ostrożny konspirator, patriota, idealista, a przy tym człowiek nadzwyczaj praktyczny.

${ }^{1}$ J. Kurtyka, Na szlaku AK („Nie”, DSZ, WiN), [w:] Z dziejów agonii i podboju: prace zebrane z zakresu najnowszej historii Polski, Kraków 2011, s. 76. 
Posiada on przede wszystkim wielką umiejętność podejścia do ludzi i ich pozyskiwania oraz sięgania po ludzi nowych ${ }^{2}$.

Po de facto utracie możliwości działania Zrzeszenia jako tajnej organizacji politycznej Łukasz Ciepliński przystępuje do likwidacji struktur. Zostało to przerwane przez aresztowania członków IV Zarządu Głównego WiN. Samego prezesa aresztowano 27 listopada 1947 r., którą to datę można uznać za koniec działalności Zrzeszenia ${ }^{3}$.

Rozpoczęło się śledztwo i liczne przesłuchania. Początkowo odbywały się w sposób pozornie normalny, jednak później prowadzano je bardzo brutalnie. W okresie od października 1947 r. do czerwca 1949 r. przesłuchiwano członków ostatniego Zarządu Głównego WiN około trzysta pięćdziesiąt razy, z tego najczęściej prezesa Łukasza Cieplińskiego - ponad sto razy ${ }^{4}$. Akt oskarżenia przeciwko działaczom IV Zarządu Głównego WiN został zatwierdzony przez dyrektora departamentu śledczego Ministerstwa Bezpieczeństwa Publicznego Józefa Różańskiego dnia 4 lipca 1950 r. i był próbą całkowitego zdyskredytowania Zarządu. Świadczyło o tym już jego pierwsze zdanie:

Sprawa przeciwko czwartej z kolei Komendy Głównej „WiN” jest historią zdrady narodowej, obozu reakcji polskiej i przedstawia jak obóz ten w walce z demokracją łączył się przeciwko narodowi z imperialistami, podporządkowując się im i stając się ich płatną agenturą 5 .

Na uwagę zasługuje już pierwsze określenie jakim jest komenda. Termin ten ściśle łączy się z organizacją zbrojną, toteż używany był w czasie działań wojennych m.in. w stosunku do kierownictwa Armii Krajowej. Odrzucając walkę zbrojną i przyjmując polityczny charakter członkowie Zrzeszenia WiN, którego pełna nazwa brzmiała Ruch Oporu bez Wojny i Dywersji „Wolność i Niezawisłość”, swoje kierownictwo określali mianem zarządu, na czele którego stał prezes. Komuniści świadomie zamieniają te terminy (zarządu i prezesa), aby włączyć to w swoją narrację o rzekomej próbie zbrojnego przewrotu, jakiego chciałby dokonać Łukasz Ciepliński wraz ze współpracownikami. Było to oczernienie szczególnie krzywdzące dla prezesa

2 S. Kluz, W potrzasku dziejowym: WIN na szlaku AK: rozważania i dokumentacja, Londyn 1978, s. 75.

${ }^{3}$ Obowiązki prezesa starał się prowadzić Mieczysław Kawalec, jednak i on został aresztowany 1 lutego 1948 r., Z.K. Wójcik, Mieczysław Marian Kawalec (1916-1951), [w:] Konspiracja i opór społeczny w Polsce 1944-1956. Słownik biograficzny, t. II, Warszawa-Kraków-Wrocław 2004, s. 216.

${ }^{4}$ Oddziałowe Biuro Udostępniania i Archiwizacji Dokumentów Instytutu Pamięci Narodowej w Warszawie [dalej cyt.: IPN BU], 944/39-44, Ciepliński Łukasz i inni, podejrzani o przynależność do oddziału WiN działającego na terenie Śląska.

${ }^{5}$ IPN BU 944/44, Ciepliński Łukasz i inni..., Akt oskarżenia, k. 395. 
ostatniego Zarządu, gdyż po objęciu prezesury Łukasz Ciepliński przystąpił również do likwidacji pozostałych jeszcze oddziałów zbrojnych, tolerowanych przez jego poprzedników, którzy nie tworzyli w prawdzie nowych oddziałów partyzanckich, jednak zdarzało się, że już istniejące przyjmowały zwierzchnictwo Zrzeszenia ${ }^{6}$. Łukasz Ciepliński od samego początku nowej konspiracji wskazywał na kształtowanie postaw i ducha w polskim społeczeństwie, a w walkach zbrojnych widział zagrożenie wojny domowej, której za wszelką cenę chciał uniknąć.

W pierwszym zdaniu było również oskarżenie o walkę z demokracją, czyli całkowite odwrócenie faktycznego celu istnienia Zrzeszenia WiN. Zarzucano też walkę przeciwko narodowi, bez jednak doprecyzowania, jaki naród miano na myśli. Pojęcie wroga narodu czy ludu było często wykorzystywane w propagandzie komunistycznej. Dla odbiorcy takiego przekazu naród oznaczał jego własny, w tym przypadku polski, ale komunizm z założenia jest przeciwny idei różnych, niezależnych narodów. Jeśli zaś przyjmie się punkt widzenia ówczesnej władzy, nieakceptowany przez społeczeństwo polskie, to można posłużyć się nazwami narodu socjalistycznego, czy wręcz sowieckiego. Przy takim założeniu rzeczywiście WiN był słusznie przedstawiany jako niebezpieczny wróg, lecz nie była to zbrodnia pojmowana w sposób uniwersalny, a jedynie forsowana przez propagandę narzuconego siłą nowego porządku. W takim kontekście można uznać za prawdopodobne świadome niewyostrzanie tego terminu. Nie oznacza to jednak, że zrezygnowano z użycia swojego nazewnictwa; jest bowiem mowa o obozie reakcji oraz imperialistach. Cały akt oskarżenia i proces sądowy był utrzymany w takim tonie, aby całkowicie zdyskredytować nie tylko IV Zarząd Główny WiN, ale całe środowisko niepodległościowe, gdyż takie zarzuty mogli odnieść do wszystkich zaangażowanych na rzecz odzyskania przez Polskę suwerenności.

Postępowanie sądowe, które rozpoczęło się 5 października 1950 r., było przykładem typowego procesu pokazowego z czasów stalinowskich. Oskarżeni byli przygotowani odpowiednio wcześnie, aby ich wygląd nie zdradzał stosowanych na nich tortur i ciężkich warunków więziennych. Na rozprawę dawano nowe ubrania oraz strzyżono. Zabiegi te miały pozorować dobre traktowanie więźniów. Jeszcze staranniej przykładano się, aby proces przebiegł wedle wcześniej ustalonego scenariusza. W celu odpowiedniego przygotowania społeczeństwa i narzucenia mu swojego przekazu wykorzystano podporządkowane sobie prasę i radio. Zadaniem spikerów i publicystów było urobienie odbiorców, aby na czas rozprawy mieli już wyrobiony, wrogi stosunek do oskarżonych. Przebieg postępowania sądowego był również

\footnotetext{
${ }^{6}$ Z. Lazarowicz, „Klamra” - mój ojciec, Wrocław 2009, s. 211.
} 
relacjonowany. Wśród słuchających tych przekazów był Jan Łopuski, żołnierz AK związany z Rzeszowszczyzną. W swojej książce tak wspomina:

Pewnego jesiennego wieczoru 1950 r., po całodziennej pracy odpoczywałem [...]. Nagle zorientowałem się, że z odbiornika płynie znajomy mi głos. W toczącym się przed Wojskowym Sądem Rejonowym w Warszawie procesie członków tak zwanej komendy głównej WiN zeznania składał Łukasz Ciepliński. Mówił dobrze mi znanym, spokojnym, jakby przytłumionym głosem, ważył słowa. Nieco później osławiona komentatorka Polskiego Radia Wanda Odolska chrapliwym, przesączonym jadem nienawiści głosem smagała oskarżonych, piętnowała ich jako najbardziej ohydnych zaprzańców i zdrajców ojczyzny $[\ldots]^{7}$.

Jan Łopuski był dobrze zorientowany w sytuacji. Nie tylko znał Łukasza Cieplińskiego z czasów działalności w Armii Krajowej, ale sam był również aresztowany i przesłuchiwany przez sowieckich oficerów. Nie przyjmował propagandy wymierzonej w członków ostatniego Zarządu Głównego WiN. Przy słowie komenda wyjaśnił w przypisie, że jego użycie było komunistycznym kłamstwem mającym przedstawić WiN jako zbrojną organizację. W swojej relacji zwrócił też uwagę na różnice $\mathrm{w}$ wypowiedziach między opanowanym Cieplińskim, a wściekle atakującą oskarżonych komentatorką. Wspomnienia Jana Łopuskiego są bardzo ważnym głosem świadka historii, który był mocno zaangażowany w walkę o niepodległość Polski. Natomiast proces i medialne relacje były kolejną odsłoną walki komunistycznej władzy nie tylko z samym IV Zarządem Głównym WiN, ale również z właściwą pamięcią i znaczeniem organizacji w świadomości społeczeństwa polskiego.

Niezwykle intrygującym dokumentem przechowywanym przez organy bezpieczeństwa jest pismo z 10 października 1950 r., skierowane do Rejonowego Sądu Wojskowego w Warszawie, obecnie będące w zbiorach Instytutu Pamięci Narodowej. Podpisane zostało jako list Robotników z Wrocławia, a jego treść wskazuje na ludzi prostych, wyrażających w sposób otwarty swoje zbulwersowanie tym, jak niszczone było podziemie niepodległościowe. List ten był odpowiedzią na proces IV Zarządu Głównego WiN, a jego autorzy nie tylko wyrażali swoje oburzenie, ale również zapewnili, że nie uwierzyli w propagandę wymierzoną w Cieplińskiego i jego towarzyszy. Przeciwnie, byli świadomi, że to właśnie członkowie Zrzeszenia WiN walczyli o prawdziwą wolność Polski. Ich poświęcenie sprawiło, że robotnicy postanowili się o nich upomnieć, nie patrząc na grożące konsekwencje. W liście tym zawarta jest również gorycz i bunt przeciwko rzeczywistości

7 J. Łopuski, Losy Armii Krajowej na Rzeszowszczyźnie (sierpień-grudzień 1944). Wspomnienia i dokumenty, Warszawa 1990, s. 336. 
zgotowanej społeczeństwu polskiemu przez totalitarną władze ${ }^{8}$. Prawdopodobnie dokument ten zachował się, gdyż poszukiwano nadawcy lub grupy nadawców, odpowiedzialnych za jego napisanie. Stanowi on świadectwo, że propaganda komunistyczna nie była tak skuteczna, jak tego chciała ówczesna władza. Piszący go nie tylko zdawali sobie sprawę z kłamstw w stosunku do sprawy ostatniego Zarządu Głównego WiN, ale również rozumieli, że ogólny obraz rzeczywistości przekazywany przez komunistów jest fałszywy. Jednak na szczególną uwagę zasługuje tu stwierdzenie przez robotników, że jeśli zabraknie takich ludzi jak Łukasz Ciepliński i jego współpracownicy, to wówczas oni wezmą sprawy w swoje ręce i komuniści poniosą odpowiedzialność za popełnione zbrodnie ${ }^{9}$. List został napisany w 1950 r., kiedy nie istniała jeszcze „Solidarność”, ale można odczytać z niego jeśli nie gotowość do walki, to $\mathrm{z}$ całą pewnością otwartość na taką ewentualność.

Wyrok wykonano 1 marca $1951 \mathrm{r}$. Strzałem w tył głowy zostali zamordowani między godziną 20:00, a 20:45 w odstępach po 5 minut kolejno: Łukasz Ciepliński, Józef Batory, Karol Chmiel, Mieczysław Kawalec, Adam Lazarowicz, Franciszek Błażej, Józef Rzepka ${ }^{10}$. Nie wydano rodzinom ciał, ani rzeczy osobistych. Odebrano im prawo nawet do pochówku. Rzuceni do dołu śmierci mieli tam pozostać na zawsze, wraz z pamięcią o nich oraz ideałami, dla których żyli. Natomiast Ludwik Kubik miał spędzić w więzieniu resztę życia. Sprawa wydawała się ostatecznie zamknięta.

Pomimo tak bezwzględnej walki pamięć o członkach IV Zarządu Głównego WiN trwała i nie przestano upominać się o ich godne uczczenie. Wraz z odwilżą i amnestią z 1956 r. został zmniejszony wyrok Ludwikowi Kubikowi. Ostatecznie wyszedł na wolość w 1957 r., a wraz z nim bezpośrednie świadectwo z tamtych wydarzeń oraz skrzętnie przechowywane przez niego grypsy Łukasza Cieplińskiego. Ostatni prezes Zrzeszenia WiN pozostawił po sobie bogaty zbiór grypsów pisanych w celi śmierci, które następnie przekazał Kubikowi. Zarówno pod względem treści, jak i ilości stanowią swoisty fenomen. Przepełnione są wiarą w ostateczne zwycięstwo i odzyskanie przez Polskę niepodległości. Znajdują się tam słowa otuchy dla bliskich, prośba o przebaczenie oprawcom, a także przesłanie na przyszłość, które szczególnie kierował do swojego syna Andrzeja. Wyłania się z nich obraz człowieka pogodzonego ze śmiercią, rozmodlonego oraz zatroskanego o losy bliskich, których pozostawił. Nie brakuje w nich również konkretnych wskazówek;

${ }^{8}$ IPN BU 0259/39, Akta kontrolno-śledcze w związku z przynależnością do ZWZ AK i WiN, przeciwko: Łukasz Ciepliński, imię ojca Franciszek, ur. 26-11-1908/1913 r. i innym. Oskarżony z art. 1 Dekretu o Ochronie Państwa z 30-10-1944 r. Wyrokiem WSR w Warszawie z dn. 14-10-1950 r. skazany na karę śmierci, List robotników z Wrocławia, t. 1, k. 128-129.

9 Ibidem.

${ }^{10}$ IPN BU 944/67, Ciepliński i inni..., Protokoły wykonania wyroków śmierci, k. 244-256. 
radził synowi, aby uczył się języków w szczególności angielskiego. Lektura grypsów zdradza nam zdolności literackie Łukasza Cieplińskiego, można w nich bowiem odnaleźć co najmniej dwa wiersze, choć ani okoliczności, ani obecność w celi donosicieli nie sprzyjały tworzeniu ${ }^{11}$. Za pomocą przekazanych grypsów Łukasz Ciepliński niejako przemówił za grobu. Zostały one po latach wydane i są obecnie ogólnodostępne, co jeszcze bardziej potęguje ich przekaz.

Nie tylko rodziny pielęgnowały pamięć o pomordowanych, ale również liczne środowiska patriotyczne. Szczególnie starano się przechować historię prezesa IV Zarządu Głównego WiN, Łukasza Cieplińskiego. W trakcie Katolickiego Tygodnia Historycznego w 1968 r. w domu katechetycznym przy kościele Farnym w Rzeszowie prezentowano referaty, wśród których znalazło się wystąpienie zatytułowane: Pułkownik Łukasz Ciepliński „Antek”, „Pług” w naszej pamięci. Po spotkaniu ukazała się w Tygodniku Powszechnym krótka notka o tym wydarzeniu ${ }^{12}$. Nie zostawiono tego bez odpowiedzi. Uznano to za sprawę tak istotną, że zajęło się nią Ministerstwo Spraw Wewnętrznych. Ministerstwo zleciło napisanie propagandowego artykułu na łamach czasopisma „Perspektywy”. Zadanie służące szkalowaniu Łukasza Cieplińskiego powierzono Jackowi Wilanowskiemu ${ }^{13}$. Zamówiony artykuł ukazał się 17 lipca 1968 r. i miał całkowicie zdyskredytować prezesa i jego środowisko ${ }^{14}$. Pomimo upłynięcia osiemnastu lat komunistyczna władza nadal bacznie śledziła tego typu zdarzenia. Reakcja była natychmiastowa i zaangażowani byli w nią ludzie na najwyższym szczeblu.

W 1972 r. po chorobie zmarł Andrzej, jedyne dziecko Łukasza Cieplińskiego, ostatniego prezesa Zrzeszenia WiN. Nie doczekał się upadku komunizmu i możliwości swobodnego pielęgnowania pamięci o ojcu i jego środowisku. Ostatni prezes IV Zarządu Głównego WiN wiązał z synem nadzieję kontynuacji swoich ideałów. Prosił go w grypsie o spisanie losów swoich podkomendnych z czasów Armii Krajowej. Początkowo sam chciał to uczynić, ale gdy stało się to niemożliwe, przekazał to zadanie synowi. Prawdopodobnie Andrzej mógłby się tego podjąć, gdyż od dzieciństwa przejawiał zdolności literackie, ale jego wczesna śmierć, miał jedynie 25 lat, ostatecznie przekreśliła te plany. Jednak pokazuje to, jak bardzo Łukasz Ciepliński był świadomy znaczenia przekazywanej pamięci o tamtych wydarzeniach.

${ }^{11}$ E. Jakimek-Zapart, Nie mogłem inaczej żyć... Grypsy Łukasza Cieplińskiego z celi śmierci, Kraków 2008.

12 J. Draus, Tygodnie kultury chrześcijańskiej, „Tygodnik Powszechny” 1968, nr 19, s. 1.

${ }^{13}$ IPN BU, Akta kontrolno-śledcze..., k. 323.

${ }^{14}$ G. Brzęk, Wierny przysiędze. O Łukaszu Cieplińskim „Pługu” komendancie IV Komendy Głównej WiN, Lublin 1991, s. 102. 
W pierwszym roku przemiany ustrojowej w Polsce w biuletynie „Solidarność Trwa" ukazał się artykuł Jerzego Klusa. Autor przypominał o Cieplińskim jednocześnie ubolewając, że taka postać odchodziła stopniowo w zapomnienie:

Jest w Rzeszowie ulica Iwana Turkiewicza, lecz nie ma ulicy płk [pisownia oryginalna] Łukasza Cieplińskiego. Jakże niewielu mieszkańców naszego miasta wie dziś cokolwiek o tym człowieku, bohaterskim dowódcy Inspektoratu AK, a późniejszemu dowódcy IV ZG WiN [...]. Nie ma on w Rzeszowie ulicy, nie ma pomnika, nie ma nawet tablicy pamiątkowej ${ }^{15}$.

Postulat nazwania ulicy i to jednej z głównych zgłaszał również Brzęk w swojej pracy z $1991 \mathrm{r}$.:

Sprawiedliwość dziejowa i honor Polaka nakazują nam, aby ppłk. Łukasza Cieplińskiego [...] zrehabilitować, a jedną z głównych ulic Rzeszowa nazwać Jego imieniem ${ }^{16}$.

Po udanych zmaganiach z komunistyczną władzą pierwsze lata przemian $w$ Polsce niosły jeszcze większe zagrożenie, jakim było zapomnienie. W ogromie zmian jakie dotykały każdego w Polsce przeszłość wydawała się bardziej odległa niż zwykle. Świadomi tego działacze patriotyczni wiedzieli, że ich walka o pamięć i faktyczną rolę IV Zarządu Głównego WiN nadal trwa.

Pod koniec 1989 r. ks. Michał Sternal podczas udzielanego wywiadu dla tygodnika „San” wystosował apel do ówczesnego ministra sprawiedliwości. Domagał się zrehabilitowania ostatniego prezesa WiN, a także całego Zrzeszenia. Pod wpływem tego apelu podjęto pierwsze kroki zmierzające do odszukania i zbadania akt sądowych sprawy. W styczniu 1992 r. Zarząd Główny Stowarzyszenia Społeczno-Kombatanckiego „Wolność i Niezawisłość" podjął starania, aby unieważnić wyrok z 14 września 1950 r., które zakończyły się sukcesem. Sąd Warszawskiego Okręgu Wojskowego postanowieniem z 17 września 1992 r. uznał wyrok za nieważny. Sąd uznał, że skazani, działali na rzecz niepodległości Polski ${ }^{17}$. W ten sposób zakończyła się batalia o dobre imię IV Zarządu Głównego WiN. Państwo przyznało rację środowisku patriotycznemu, dlatego w pełni legalnie można było przystąpić do upamiętnienia pomordowanych.

Na przełomie lat 80. i 90. podejmowano kolejne inicjatywy mające na celu uczczenie IV Zarządu Głównego WiN. Dzięki staraniom kombatantów, działaczy „Solidarności” i lokalnej społeczności umieszczono tablice na ścianie

15 J. Klus, Wszyscy jesteśmy stalinowcami „Solidarność Trwa; biuletyn informacyjny regionalnej komisji wykonawczej NSZZ „Solidarność” w Rzeszowie” 1989, nr 124, s. 4.

${ }^{16}$ G. Brzęk, Wierny przysiędze..., s. 103.

17 E. Jakimek-Zapart, Nie mogłem inaczej żyć..., s. 56. 
kościoła w Staromieściu i ojców Bernardynów w Rzeszowie. Kolejną dodano na rodzinny grób żony i syna Łukasza Cieplińskiego na cmentarzu Pobitno, który stał się symboliczną mogiłą prezesa Zrzeszenia WiN. W Rzeszowie znajduje się również symboliczny grób wszystkich pomordowanych członków Zarządu, na cmentarzu komunalnym Wilkowyja. Nie poprzestano na tym, ale podjęto starania, aby odszukać miejsce, gdzie pogrzebano ich doczesne szczątki. Poszukiwania te kontynuuje Instytut Pamięci Narodowej, który szuka wszystkich ofiar totalitarnego terroru pozostających bez imiennego grobu. Prowadzone były w tym celu badania na kwaterze „Ł” Cmentarza Wojskowego na Powązkach w Warszawie. Pierwszy etap prac archeologiczno - ekshumacyjnych zakończono $2012 \mathrm{r}^{18}$ Drugi etap był szczególnie istotny z uwagi na członków IV Zarządu Głównego WiN. Dnia 27 maja 2013 r. w „Naszym Dzienniku”, gazecie na bieżąco przedstawiającej kolejne etapy prac IPN na kwaterze „Ł”, poinformowano, że badacze szczątków odnaleźli przy czaszkach trzy medaliki z wizerunkiem Matki Boskiej. Jeden z nich został odnaleziony na żuchwie ofiary. Była to bardzo ważna informacja, gdyż jak sam pisał w grypsach i o czym wspominają świadkowie, Łukasz Ciepliński przed śmiercią miał połknąć medalik, który udało mu się ukryć przez cały czas przebywania w więzieniu. Zarówno autor artykułu jak i badacze, zastanawiali się, czy nie odnaleziono wówczas szczątków Łukasza Cieplińskiego ${ }^{19}$. Gdyby tak było, to można z dużą dozą prawdopodobieństwa uznać, że odnaleziono również pozostałych. W dniu tym wiadomość pojawiła się również na wielu portalach informacyjnych, powołujących się na ten artyku $^{20}$. Odkrycie to było bardzo ważne, jednak pewność dać mogą jedynie badania genetyczne. Niestety ta procedura jest długa i kosztowna. Ekshumację zakończono w 2017 r., ale nie udało się jeszcze ustalić tożsamości wszystkich odnalezionych. Nadal nie ma informacji na temat członków IV Zarządu Głównego WiN.

Kontynuowano przywracanie pomordowanym należnego miejsca w świadomości społeczeństwa polskiego. Inicjatywy były przeważnie lokalne i oddolne, ale to nie zrażało zaangażowane osoby w walkę o pamięć o Łukaszu Cieplińskim i jego współpracownikach. Uwzględniono w końcu postulat zgłaszany m.in. przez Gabriela Brzęka oraz Jerzego Klusa. Jedna z głównych ulic Rzeszowa otrzymała imię ostatniego prezesa Zrzeszenia WiN. Swoją ulicę z tym patronem ma też Kraków, a od 2012 r. również Ostrołęka. Łukasz Ciepliński został obrany patronem szkół: w 1995 r. SP nr 504 w Gnojnicy

18 www.ipn.gov.pl, dostęp: 10.05.2013.

19 P. Czartoryski-Sziler, Medalik z żuchwy, „Nasz Dziennik” 2013, nr 122 (4661), s. 1.

${ }^{20}$ Między innymi w portalach: polskieradio.pl, m.gazeta.pl, fakty.interia.pl, kresowiacy.pl, niezależna.pl, dostęp: 27.05.2013. 
Woli i w 1996 r. SP nr 28 w Rzeszowie. W 2001 r. upamiętnienie miało już charakter ogólnopolski i państwowy, dnia 14 marca Sejm PR w specjalnej ustawie oddał hołd pomordowanym i prześladowanym działaczom Zrzeszenia WiN, a 3 maja 2007 r. Łukasz Ciepliński został pośmiertnie odznaczony Orderem Orła Białego przez ówczesnego prezydenta RP Lecha Kaczyńskiego. Dzienna data śmierci członków IV Zarządu Głównego WiN stała się również datą ustanowionego 2011 r. Narodowego Dnia Pamięci „Żołnierzy Wyklętych". Organizuje są wtedy liczne marsze i uroczystości, gdzie również wspomina się bohaterskich Winowców. Syn Adama Lazarowicza wydał w 2009 r. książkę o swoim ojcu zatytułowaną: „Klamra” - mój ojciec. Powstał nawet komiks historyczny przedstawiający życie ostatniego prezesa Zrzeszenia WiN - Wbrew nadziei. Opowieść o Łukaszu Cieplińskim ps. „Pług”.

Decyzją Ministerstwa Obrony Narodowej z dnia 28 lutego 2013 r. zamordowani członkowie IV Zarządu Głównego WiN zostali pośmiertnie awansowani o jeden stopień, w tym Łukasz Ciepliński na stopień pułkownika ${ }^{21}$. Mieszkańcy Rzeszowa przystąpili również do budowy grupowego pomnika ku czci ostatniego Zarządu Głównego WiN. Ogłoszono konkurs na projekt, który zwyciężył Karol Badyna. Odsłonięcie planowano na setną rocznicę urodzin Cieplińskiego, która przypadała 26 listopada 2013 r. ${ }^{22}$ Plan ten udało się zrealizować, choć nie wykorzystano całego potencjału projektu. Nie udało się bowiem dołączyć części multimedialnej. Lokalizacja pomnika jest bardzo istotna, gdyż mieści się on przy ulicy Łukasza Cieplińskiego w Rzeszowie. Pomnik składa się z wizerunku Cieplińskiego i sześciu mniejszych popiersi: Adama Lazarowicza, Mieczysława Kawalca, Józefa Batorego, Franciszka Błażeja, Józefa Rzepkę oraz Karola Chmiela. Góruje nad nimi podobizna Łukasza Cieplińskiego, umieszczona powyżej krat, co ma wskazywać, że nawet w więzieniu zachował swoją wolość i wiarę. Dowodem tego jest fragment grypsu, którego treść jest obok wizerunku ostatniego prezesa. Pomnik jest bardzo wymownym świadkiem historii członków IV Zarządu Głównego WiN i dowodem, że pamięci o nich nie udało się wymazać.

Historia walki o pamięć i znaczenie IV Zarządu Głównego WiN wpisuje się w dzieje całego środowiska niepodległościowego, prześladowanego i często brutalnie zwalczanego przez działaczy nowego systemu, wprowadzanego siłą nie tylko w Polsce. Ukazuje, jak władza komunistyczna starała się zniekształcić, a następnie wymazać pamięć o Zarządzie wykorzystując do tego

${ }^{21}$ Informacja uzyskana podczas konferencji na Uniwersytecie Rzeszowskim poświęconej obchodom Narodowego Dnia Pamięci „Żołnierzy Wyklętych” 1 marca 2013 r. oraz M. Kamieniecki, Pułkownik Ciepliński!, „Nasz Dziennik” 2013, nr 51 (4590) i nasz dziennik.pl

${ }^{22}$ www.pomnikcieplińskiego.pl, dostęp: 1.03.2013. 
wszystkie dostępne sobie środki. Osobę prezesa Łukasza Cieplińskiego można porównać do wielu innych pomordowanych za działania służące odzyskania przez Polskę suwerenności. Szczególnie podobna jest tu postać Witolda Pileckiego, wyznającego te same wartości i posiadającego tożsamy stopnień zażyłości w wierze. Obydwaj podkreślali świadomość swojego wyboru i prosili bliskich o przebaczenie sprawcom. Łukasz Ciepliński nie miał możliwości nawet pożegnania się z rodziną, najprawdopodobniej to było powodem powstania tak bogatych grypsów pisanych z celi śmierci. W artykule została przedstawiona walka z pamięcią i znaczeniem IV Zarządu Głównego WiN na przykładach, gdyż obecnie niezwykle trudno byłoby przedstawić wszystkie wydarzenia, w których wspomniana się WiN, szczególnie ostatniego prezesa. Przy różnego rodzaju uroczystościach patriotycznych przytacza się fragmenty z grypsów Łukasza Cieplińskiego.

Artykuł ukazuje bardzo heroiczny przypadek, ale również daje bardzo pozytywne przesłanie. Pielęgnowana i kultywowana pamięć okazała się silniejsza od przemocy władzy. Temat ten jest też doskonałym pretekstem do pochylenia się nad rolą pamięci i potrzebą przechowywana wspomnień oraz przekazywania ich kolejnym pokoleniom. Jest to również pewnego rodzaju pocieszenie dla samych historyków, zwłaszcza teraz, kiedy to nawet z tego środowiska dochodzą głosy podważające dalszy sens istnienia historii jako nauki.

\section{BIBLIOGRAFIA}

\section{Źródła}

AIPN BU, Ciepliński Łukasz i inni, podejrzani o przynależność do oddziału WiN działającego na terenie Śląska, IPN BU 944/39-44.

AIPN BU, Ciepliński Łukasz i inni, podejrzani o przynależność do oddziału WiN działającego na terenie Śląska, IPN BU 944/67.

Akta kontrolno-śledcze w związku z przynależnością do ZWZ AK i WiN, przeciwko: Łukasz Ciepliński imię ojca Franciszek, ur. 26-11-1908/1913 r. i inni. Oskarżony z art. 1 Dekretu o Ochronie Państwa z 30-10-1944. Wyrokiem WSR w Warszawie z dn. 14-10-1950 r. skazany na karę śmierci, IPN BU 0259/39 t. 5. 


\section{Opracowania}

Brzęk G., Wierny przysiędze. O Łukaszu Cieplińskim „Pługu” komendancie IV Komendy Głównej WiN, Lublin 1991.

Czartoryski-Sziler P., Medalik z żuchwy, „Nasz Dziennik” 2013, nr 122 (4661).

Draus J., Tygodnie kultury chrześcijańskiej, „Tygodnik Powszechny” 1968, R. 40, nr 19 (1924).

Jakimek-Zapart E., Nie mogłem inaczej żyć... Grypsy Łukasza Cieplińskiego z celi śmierci, Kraków 2008.

Klus J., Wszyscy jesteśmy stalinowcami, „Solidarność Trwa; biuletyn informacyjny regionalnej komisji wykonawczej NSZZ „Solidarność” w Rzeszowie” 1989, nr 124.

Kluz S., W Potrzasku dziejowym: WiN na szlaku AK: rozważania i dokumentacja, Londyn 1978.

Kurtyka J., Na szlaku AK („Nie”, DSZ, WiN), [w:] Z dziejów agonii i podboju: prace zebrane z zakresu najnowszej historii Polski, Kraków 2011.

Lazarowicz Z., „Klamra” - mój ojciec, Wrocław 2009.

Łopuski J., Losy Armii Krajowej na Rzeszowszczyźnie (sierpień-grudzień 1944). Wspomnienia i dokumenty, Warszawa 1990.

Anna Wolanin

\section{THE FIGHT TO RESTORE THE POLISH COLLECTIVE MEMORY OF THE HISTORY OF THE FOURTH MAIN DIRECTORATE OF THE FREEDOM AND INDEPENDENCE AFTER 1950}

\footnotetext{
$\mathrm{T}$

he article presents the struggles of patriotic activists with the communist authorities. Initially, the Communists wanted to destroy the good name of the fourth Main Directorate of „Freedom and Independence” and all independence activists, and then remove any trace of their existence. After a cruel investigation, members of the fourth Main Directorate were tried in a demonstration process. The course of the trial was reported on the radio. This was not without an answer. Among the voices of indignation was the letter of the Wrocław laborers, kept by the Security Office. The Church, and later Solidarność, also joined the battle for memory. All activities undertaken to preserve the memory of the fourth Main Directorate were stigmatized by the then communist authorities. Nevertheless, further activities were carried out. Symbolic graves were created, because the resting place of their bodies is not known today. An important and extremely rich source are secret messages written by the president of the fourth Main Directorate - Łukasz Ciepliński from the death cell. Archival sources, memories, press materials and studies were used to prepare the article.
}

Keywords: Łukasz Ciepliński, Freedom and Independence, Fourth Main Directorate of Freedom and Independence, memory. 